\title{
The effect of think pair share method and students' creativity on students' learning outcome
}

\author{
Joni Indra Wandi ${ }^{1}$, Azwar Ananda ${ }^{2}$, Buchari Nurdin ${ }^{3}$ \\ ${ }^{123}$ Universitas Negeri Padang , Padang - Indonesia, (jhoniindra889@gmail.com)
}

\begin{abstract}
The aim of this study was to explore the effect of think pair share method and students' creativity toward students' learning outcome. This research was begun by doing the related surveys for current situation of social science in the history subject where teaching the subject did not provide yet the expected learning outcome. For that reason, it needed a think pair share method to strengthen students' creativity in order to improve student's learning outcome as well as their self-evaluation in enhancing their creativity and learning competence. This research used quantitative approach with survey method. The collection of the data used questionnaires, interviews, documentary studies, and field notes. Quantitative data were analyzed by using an experimental method. Data analysis used multiple linear regression and correlation test. The experimental results on the three classes showed that think pair share method and students' creativity can improve students' learning outcome better than conventional class, but there is no interaction between the think pair share method and creativity with the eighth grade students' learning outcomes. Teacher could use this model to Junior High School students' level for improving students' learning outcome in the lesson of social science.
\end{abstract}

Keywords: think pair share, students' creativity, learning outcome

\section{Introduction}

Educational process which is made based on planned education system is expected to offset changes that occur in the life of society, nation, and state. For that reason, it requires the pay attention seriously for the learning process to the schools that could not be separated from the role of the teacher. The Efforts of improving the education quality can be implemented through a good learning process so as to create the students' creativity and student learning outcomes.

Students' creativity is needed in determining a solution, it was related to the materials that the students get in touch with previous students in searching the solution of problems given. As dictated by Lawrence, Foster, \& Tieso (2015)argued that creativity is the ability to create new combinations based on the data, information, or elements that already exist or have been previously known, that is all the experience and knowledge that has been obtained by a man during his life either in the school, family, and society. According to (Hwang (2017)stated that creativity is a modification of something 
that already exists into a new concept. In other words, there are two old concepts that combined into a new concept. Meanwhile according to Yang, Lee, Hong, \& Lin(2016)stated that creativity is the result of interaction between the individual and the environment, the ability to create new combinations, based on the data, information, or any existing items or previously known.

Increasing students' creativity is very important in learning, process especially in social studies. It is due to the social science goal is to establish the mindset of students' creative and responsivse to community socialdevelopment. As explained by Lawrence stated that the purpose of social education is developing the students' thinking skills, attitudes and values as an individual, social and the cultural beings(Lawrence et al., 2015).

Student creativity is needed to determine a solution, it related to previous material and previous knowledge of students about the problems to find out the resolution of it. As dictated by AlDababneh, Al-Zboon, \& Ahmad (2017)argued that creativity is the ability to create new combinations based on the data, information, or elements that already exist or have been previously known, that is all the experience and knowledge that has been obtained by a person during his life either in the school, family, and community

In social science the curriculum at the level of secondary school subjects should be integrated method. The integrated curriculumaims to 1) students are familiar with concepts related to people's lives and environment; 2) have the basic ability to think logically and critically, curiosity, inquiry, problem solving, and social skills in the life; 3 ) have the commitment and social awareness of values and humanity; and 4) have the ability to communicate, collaborate and to compete in a pluralistic society, either local, national, and global.

Social knowledgeis a science that examines the various disciplines of social and humanities as well as a basic human activities that is packed scientifically in order reflected on the deep insight and understanding it to the students, especially at the elementary and secondary levels.Leyshonstated that the purpose of social education is developing thinking skills, attitudes and values of learners as individuals and as social in the cultural beings (Leyshon, 2014).

In an effort to realize the objectives of social studies learning is to sharp their students' creativity and for this reason needs the right method, one appropriate method to do that is to form the creativity learning by using think pair share model. Think pair share is a cooperative learning type designed to affect the students' interaction and motivate student to find out the problem of the life, so that it will set up a students' creativity in learning their social life. Think pair share gives students the opportunity to work alone and collaborate with others. Another advantage of this study is the optimization of students' participation.

These advantages includingimproving student learning outcomes and increasing the real conceptual learning by doing the high activity such as order thinking and cooperative discussions in a group so that students are fun to learn material in the long period of time.

Based on the results of preliminary observations that researchers did from 4 to 6 January 2015 at SMPN 24 Padang obtained a description of social learning is still less encourage especially in the development of students' creativity, it was still lower, because teachers still domain in the class by using teacher centers method, besides teachers also tend to apply the social teaching by using deductive method, the teacher explained all the material in the textbook, then the student was required to answer the questions in the exercises columnon the textbook.

Indeed, there have been several interactions that teacher have been done in building the creativity in each session, for example when teachers explanation about the subject by involving learners in interactivediscussion, but not many students answered the question given by teachers, perhaps it was caused by teachers used to give a straight answer without waiting for the students to think or discuss in small groups first, so every discussion, it is impressed almost all students are not initiative to think 
and answer the question given, as well as when the teacher asks and the students asked too, none of them asked, because the class situation was not good atmosphere where almost the learner being passive, only one or two learners who want to ask, but the question was not quality this condition as if nothing conducive and nothing good impression of critical thinking in answering the question given by teacher.

As a result, the condition of passive students when they study, it leads them learning less exciting and boring, because students only hear without doing thinking for learning. This condition is often the authors found, some students were sleepy when his or her teacher explains the subject matter in front of class;it was a monotonous learning atmosphere that leadsstudents to be less eager to follow the lessons.

Based on the problems above, so the aim of this study is to explore the effect of think pair share method and students' creativity toward students' learning outcome in the subject of social science at eighth grade student at SMP Negeri 24 Padang. This research was begun by doing the related surveys for current situation of social science in the history subject where teaching the subject do not provide yet the expected learning outcome. For that reason, it needs a think pair share method to strengthen students' creativity in order to improve student's learning outcome as well as their self-evaluation in enhancing their creativity and learning competence.

\section{Method}

This study used an experimental quantitative approach with survey design. According to (Creswell W John, 2014)stated that experimental quantitative study is to test the hypothesized among variables. The hypothesis of this study will be verifiable. It describes that the hypothesis have strong relationship between variables. This research used two variables are creativity and students' learning outcome to compare between the effectiveness method of think pair share as experimental class and conventional method as control class with creativity as covariate variable.Population of this study was all eight grade students of Junior High School of SMP Negeri 24 Padang. Sample was taken as much as 112 people. Research data collection techniques covered summative tests to measure students' learning outcome of social science and questionnaires to measure students' creativity. The research instruments used validation of instruments, achievement test and creativity questionnaire. Before using the instrument, all instruments should pass the validity test. The validity test was done by using the content validity through the opinion of experts to examine the contents of the test systematically and to evaluate its relevance with target that has been determined. Other instruments such as lesson plan, student worksheet handout, written test and performance test was measured by using empirical test of validity. According to Creswell W John, (2014) the validity of the test showed the extent to which a measuring device used to measure its validity and reliability. The measurement of it can be done by using product moment, the item can be considered as a valid question if it is greater than 0:30. While reliability is if all question asked of respondents trusted based on Cronbach alpha test

\section{Results and Discussion}

The implementation of think pair share methodto eight grade students of SMP Negeri 24 Padang was obtained to measure the students' learning outcome in the field of social science. Before the study was conducted, a written test was given first to determine the level of students' ability without doing any treatment at all and the result was compared with the post test. Here the pre test results of students in the two groups of experimental class and control class. 
< JONI INDRA WANDI, AZWAR ANANDA, BUCHARI NURDIN>

(The Effect of Think Pair Share Method and Students' Creativity on Students' Learning Outcome)

Table1Pretest Score in Experimental Class and Control Class

\begin{tabular}{lrrrrrrr}
\hline Pre Test & \multirow{2}{*}{ N } & \multicolumn{2}{c}{ Range } & \multicolumn{2}{c}{ Minimum } & Maximum & \multicolumn{2}{c}{ Mean } & \multicolumn{2}{c}{$\begin{array}{c}\text { Std. } \\
\text { Deviation }\end{array}$} & Variance \\
\hline Experiment & 31 & 20.00 & 70.00 & 90.00 & 77.5806 & 3.6035 & 12.985 \\
\hline Control & 32 & 20.00 & 68.00 & 88.00 & 77.5938 & 4.6271 & 21.410 \\
\hline Valid N & 31 & & & & & & \\
\hline
\end{tabular}

According to the firsttable above showed that the average score of pre test was 77.5806while the value of the control class by using the conventional method was 77.5938, Based on this evidence can be stated that the results of the pretest between experimental class and control class is not too much difference on students' learning outcome.

Therefore, researchers can conclude that based on the pretest result there was no difference of students' learning outcome between experimental class and conventional. So it need to study the result of students' post test by using think pair share (TPS) as treatment in the class when teaching was done and control class by using conventional methods like as usual teaching before posttest did. Based on the results of the data analysis processing of students' posttest can be explained as follows:

Table 2 Post Test Score in Experimental Class and Control Class

\begin{tabular}{lrrrrrrr}
\hline $\begin{array}{l}\text { Pre Test } \\
\text { Class }\end{array}$ & N & Range & Minimum & Maximum & Mean & $\begin{array}{c}\text { Std. } \\
\text { Deviation }\end{array}$ & Variance \\
\hline Experiment & 32 & 20.00 & 75.00 & 97.00 & 85.6250 & 5.8351 & 34.048 \\
\hline Control & 32 & 20.00 & 73.00 & 95.00 & 80.6313 & 6.3040 & 39.714 \\
\hline Valid N & 32 & & & & & &
\end{tabular}

According to the second table above showed that the average score of experimental class was 85.6250, while the control class with conventional method was 80.5313. After seeing the students' learning outcome of the post test above, it can be concluded that the experimental class has higher learning outcomes than control class. It means the experimentalclass can increase the students' learning outcomes better than the control class.

From analysis of Pre test and post-test to experimental and control class showed there was significant different between them as follows.

Table 3. The Comparison of Students Learning Outcome Based on Students' Creativity

\begin{tabular}{lrrrccc}
\hline \multirow{2}{*}{ Class } & \multirow{2}{*}{ Creativity } & \multirow{2}{*}{} & \multicolumn{4}{c}{ Students' Learning Outcome } \\
\cline { 5 - 8 } & & & Mean & SD & G. Max & G Min \\
\hline Experiment & High & 17 & 0.512 & 0.203 & 0.864 & 0.200 \\
\hline \multirow{2}{*}{ Control } & Low & 15 & 0.245 & 0.214 & 0.583 & -0.136 \\
\hline \multirow{2}{*}{ High } & 16 & 0.298 & 0.168 & 0.545 & 0.056 \\
& Low & 16 & 0.053 & 0.152 & 0.313 & -0.389 \\
\hline
\end{tabular}

Based on the third table above can be seen that the experimental class which taught by using think pair share method with the high creativity level got learning outcome was 0.512 , and control class by using conventional learning methodwas 0.298 , While the experimental class taught by using think pair share with low creativity level got learning outcome was 0.214 and control class with conventional learning methodwas 0.053 . 
Overall it can be concluded that there was a difference in improving student learning outcomes between high and low students' creativity both in the experimental class and control class. Then overall there was also a difference in improving student learning outcomes between low students' creativity and high students' creativity both in the experimental class and control class.

As according to the aims of this research are to answer the hypothesis of whether the method of think pair share and students' creativity is possible to give positive effect toward students' learning outcomein the field of social science better than students who taught by conventional learning methods. The result of research analysis showed that think pair share method is significantly higher than conventional method toward students' learning outcome and students' creativity in SMPNegeri of 24 Padang

Table 4. Results Analysis of Independent t-Test between Think Pair Share

And Conventional Teaching Method

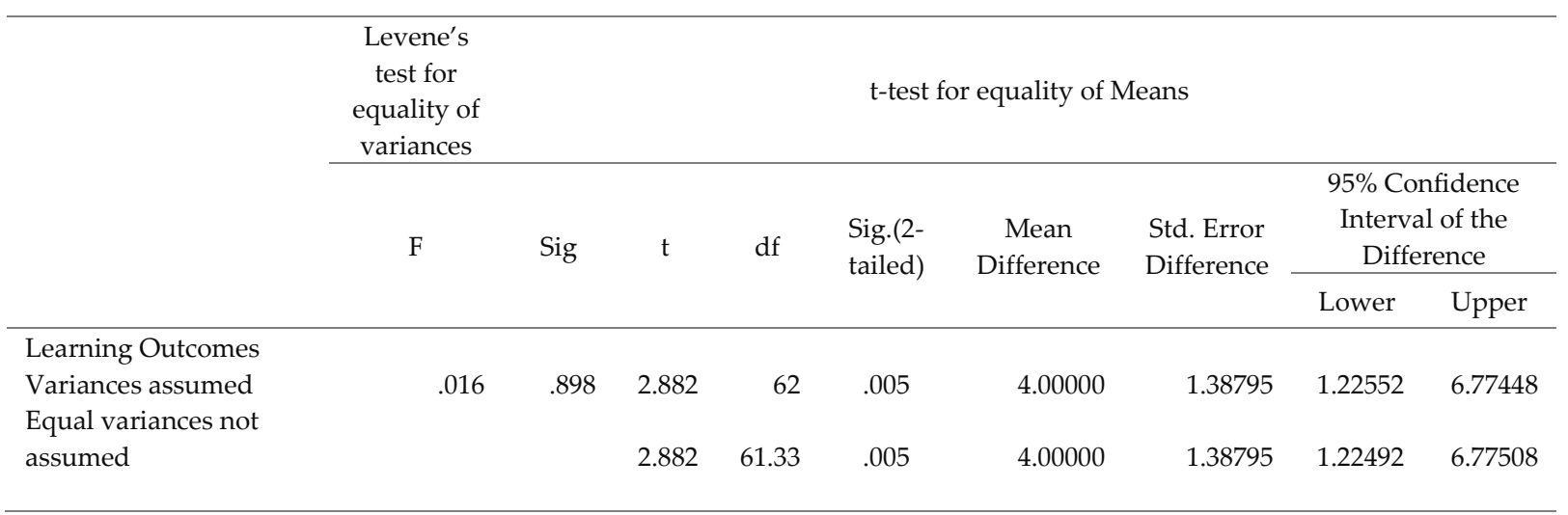

Based on the table above showed that the significant value $t_{\text {account }} 2,882$ and 0,005 . If compared to the value of $\alpha=0.05$, is significant when the value $0.005<0.05$. Itis means $H$ orejected because and is accepted, it can be concluded that the results of students' learning outcome who taught by using think pair share method is significantly higher than conventional method.

In the comparison effect between student with high creativity who taught by using think pair share method and student with high creativity who taught by conventional method showed that student with high creativity who taught by think pair share is significantly higher than the students with high creativity who taught by conventional at the eighth grade students of SMPN 24 Padang

Table 5. Results Analysis of Independent t-Test between Think Pair Share and Conventional Teaching Method on Students' Learning Outcome Based on Higher Students' Creativity

\begin{tabular}{|c|c|c|c|c|c|c|c|c|c|}
\hline & $\begin{array}{l}\text { Levene's } \\
\text { test for } \\
\text { equality of }\end{array}$ & \multicolumn{8}{|c|}{ t-test for equality of Means } \\
\hline & \multirow[t]{2}{*}{$\mathrm{F}$} & \multirow[t]{2}{*}{ Sig } & \multirow[t]{2}{*}{$\mathrm{t}$} & \multirow[t]{2}{*}{$\mathrm{df}$} & \multirow[t]{2}{*}{$\begin{array}{l}\text { Sig.(2- } \\
\text { tailed) }\end{array}$} & \multirow[t]{2}{*}{$\begin{array}{c}\text { Mean } \\
\text { Difference }\end{array}$} & \multirow[t]{2}{*}{$\begin{array}{l}\text { Std. Error } \\
\text { Difference }\end{array}$} & \multicolumn{2}{|c|}{$\begin{array}{c}95 \% \text { Confidence } \\
\text { Interval of the } \\
\text { Difference }\end{array}$} \\
\hline & & & & & & & & Lower & Upper \\
\hline Learning Outcomes & & & & & & & & & \\
\hline Variances assumed & .698 & .410 & 2.226 & 30 & .034 & 3.50000 & 1.57255 & .28842 & 6.77118 \\
\hline $\begin{array}{l}\text { Equal variances not } \\
\text { assumed }\end{array}$ & & & 2.226 & 28.93 & .034 & 3.50000 & 1.57255 & .28345 & 6.71655 \\
\hline
\end{tabular}

Based on the fifth table above, it can be proven that the significance value of both treatments were $t_{\text {account }} 2.226$ and 0.034 . When compared with significant value $\alpha=0.05$, where 0.034 is significance 
different because less than 0.05 . It means that in the significance level of 0.05 , Howasrejected and $H_{1}$ was accepted, it can be concluded that the students with high creativity who taught by think pair share method is significantly higher of students' learning outcome than the students with high creativity who taught by conventional at SMPNegeri 24 Padang

In the comparison effect between student with lowercreativity who taught by think pair share method and student with lowercreativity who taught by conventional method showed that student with lowercreativity who taught by think pair share method is significantly higher of the students' learning outcome that other wit lower creativity who taught by conventional teaching method. The analysis result can be seen in the table below:

Table 6. Results Analysis of Independent t-Test between Think Pair Share and Conventional Teaching Method on Students' Learning Outcome Based on Lower Students' Creativity

\begin{tabular}{|c|c|c|c|c|c|c|c|c|c|}
\hline & $\begin{array}{l}\text { Levene's } \\
\text { test for }\end{array}$ & \multicolumn{8}{|c|}{ t-test for equality of Means } \\
\hline & \multirow[t]{2}{*}{$\mathrm{F}$} & \multirow[t]{2}{*}{ Sig } & \multirow[t]{2}{*}{$t$} & \multirow[t]{2}{*}{$\mathrm{df}$} & \multirow[t]{2}{*}{$\begin{array}{l}\text { Sig.(2- } \\
\text { tailed) }\end{array}$} & \multirow[t]{2}{*}{$\begin{array}{c}\text { Mean } \\
\text { Difference }\end{array}$} & \multirow[t]{2}{*}{$\begin{array}{l}\text { Std. Error } \\
\text { Difference }\end{array}$} & \multicolumn{2}{|c|}{$\begin{array}{l}95 \% \text { Confidence } \\
\text { Interval of the } \\
\text { Difference }\end{array}$} \\
\hline & & & & & & & & Lower & Upper \\
\hline $\begin{array}{l}\text { Learning Outcomes } \\
\text { Variances assumed }\end{array}$ & 3.008 & .093 & 2.428 & 30 & .002 & 4.50000 & 1.31260 & 1.81931 & 7.18069 \\
\hline $\begin{array}{l}\text { Equal variances not } \\
\text { assumed }\end{array}$ & & & 2.428 & 24.04 & .002 & 4.50000 & 1.31260 & 1.79114 & 7.20886 \\
\hline
\end{tabular}

Based on the sixth table above can be proven that the significance value of both treatment were $t_{\text {account }} 3.428$ with significant value $\alpha=0.002$, If comparing the two result with alpha value 0.05 , then the result is significance different because 0.02 less than 0.05 . It means that in the significance level 0.05 , Howasrejected and $H_{1}$ was accepted, it can be concluded that the students with lower creativity who taught by using think pair share method is significantly higher of students' learning outcome than other with lower creativity who taught by using conventional teaching methods at SMPNegeri 24 Padang

The interaction between think pair share and creativity on students' learning outcomes at SMPNegeri 24 Padang can be explained in the table below :

Table 7. Interaction of Variant Analysis of Think Pair Share and Students' Creativity

\begin{tabular}{cccccr}
\hline Score & $\begin{array}{c}\text { Type III Sum of } \\
\text { Spaces }\end{array}$ & df & $\begin{array}{c}\text { Mean } \\
\text { Square }\end{array}$ & F & \multicolumn{2}{c}{ Sig } \\
\hline Corrected Model & $1160.000^{\mathrm{a}}$ & 3 & 386.667 & 23.039 & .000 \\
Intercept & 447561.000 & 1 & 447561.000 & $2.667 \mathrm{E} 4$ & .000 \\
Class & 256.000 & 1 & 256.000 & 15.253 & .000 \\
Creativity & 900.000 & 1 & 900.000 & 53.625 & .000 \\
Class\#Creativity & 4.000 & 1 & 4.000 & 238 & .627 \\
Error & 1007.000 & 60 & 16.783 & & \\
Total & 449728.000 & 64 & & & \\
Corrected Total & 2167.000 & 63 & & & \\
\hline
\end{tabular}

$\mathrm{R}$ Squared $=.535($ Adjusted R Squared $=.512)$

Based on the calculations with two way ANOVA for analysis of hypothesis test obtained Faccount 0.238 with the Significance value was 0.627 . When compared with the value of the real level $\alpha=0.05$, 
this result showed that the value of 0.627 was less than 0.05 then Howas accepted and Hiwas rejected. It can be concluded that there was no interaction between students' creativity and think pair share method on the effect to the students' learning outcomes at SMP Negeri 24 Padang.

The influence of the Think Pair Share model and creativity to improving the learning outcomes of students has strong relationship with teachers' role in the implementation of their learning model well. In this case, the teacher plays an important role in social learning by fostering the creativity of students. The findings suggest that the implementation of learning social science by teachers in secondary schools use think pair share method is one of the pedagogical abilities of teachers in developing students' creativity while attending the teaching learning process in the classroom, and this is part of the self-efficacy of teachers. Teachers believe that they have the ability to foster the creativity of students in their classes. The results of this study parallel with literature report (Ozkal, 2014)Noting that the ability of teachers in implementing the learning model of think pair share can increase students' high creativity, and the results of this study are also consistent with studies by Sulaiman Keshta \& Seif (2013)Which found that teachers who master the learning method well have the ability to develop their students' creativity. These results can be explained by measuring the success of teachers implement the learning model and mastery with any kinds of teaching material well. It means that the teacher's role is very important in encouraging the improvement of students' creativity when following the lesson in the class. (Palmer, 1992)Elaborate on this point and believes that students' success' and students' interest in the material that is taught by teachers are not separated from the ability of teachers to develop teaching materials and implementing the appropriate learning method in accordance with the teaching materials provided.

Implementation of the learning model and creativity are two important variables. Successful implementation of creative learning among students occurs supported by a learning model of Think Pair Share to construct the cooperative learning model among students to share ideas, opinions and knowledge each other in solving any kinds of problems. Think Pair Share methods encourage students to learn creative in their groups and share knowledge in solving a studied problem. So far teachers believe that creativity is a high influence on the achievement of high learning outcomes and vice versa, low creativity tend give lower learning outcome. There are some explanations that may be described in these findings is to increase student learning outcomes, then the teacher must build a fun learning method based on collaborative and sharing the idea of one and other student in a group like a think pair share method. Rubenstein, McCoach, \& Siegle (2013)Supports this explanation, because they reported that teachers were able to build the value of creativity and professional development themselves, then it will affect the success of their students' learning, especially in developing students' learning behavior of creative. However, in this study, the absence of interaction between teachers attainment and their implementation ability to create a good atmosphere learning model and creativity to improve student learning outcomes. This condition may be caused by the behavior of the students were still unruly and limited time allocation causes creative thinking of students is limited too,

These findings are also different with studies of Plucker, J., \& Beghetto, (2003)revealed that the interaction between teacher's ability of applying the learning model well and creativity on the increasing of students' learning outcomes. This condition is quietly different with the conditions of our study because the duration study of Plucker and Beghetto is long enough and the implementation of learning group involved high school students where their emotional and cognitive have been more maturity than middle school students, in addition to the additional possibility is that the teachers in the study of Plucker and Beghetto showed a positive response in every learning process which involves the creativity of students, whereas in this study, we did not measure the response of teachers and students, so there is no improvement treatments as practiced like in the research of Plucker, J., \& Beghetto, (2003). 
Nevertheless, the results showed that there is a positive influence between the learning models of think pair share on the improvement of students' learning outcome. The results of this study consistent with the research of Cooper (2018)stated that think pair share model can improve students' learning outcomes. Likewise with the creativity that is believed can improve student learning outcomes as well and proven in this research indicate by highly creative students will be produce highly learning outcome to the student in study of social science by using think pair share method and finally impact on improving students' learning outcomes.

An important finding of this study is that the experimental group students made significant progress towards creativity and students' learning outcomes than the control group. Although additional research is needed to confirm the cause of nothing interaction between the method of think pair share applied and creativity in enhancing the students' learning outcomes, these findings provide empirical evidence to confirm that the implementation of the model has a positive effect on learning outcomes, as well as creativity is also give a positive influence on learning outcome, but both of these variables did not have any interaction each other toward improving students' learning outcomes. Empirical studies on the further development of student creativity need to be explored in a new study Kind \& Kind (2007), which explores improving students' learning outcomes and its linearity with improving the students' creativity in the classroom for each every learning process of cooperative to social science subjects. The study recommends to conduct further research related the influence of the scientific creativity thinking on students' creativity and its relationship with student achievement based on the same learning methods and the same learning strategy.

The second important finding of this study is that an effective strategy is to develop creative thinking skills. It has been identified, respectively, through qualitative data from classroom observations along with interviews. In addition, the influence of creativity on learning outcomes showed a positive association supported by quantitative data analysis of student achievement progress in the experimental class, although the interactions were not related.

Today, based on our understanding, there is not a creative learning empirical study that focused on the investigation to teaching strategies in order to strengthen students' creative thinking. Further studies in this regard can certainly provide new insights in the literature of this field. Based on previous literature shows that new studies and third most common hypothesis is to look at the interaction between learning method and creativity to the learning outcomes, whereas all of the academic engagement, behavior engagement and social engagement not been studied yet. To the next authors recommend to evaluate the effects and interaction between learning method is not only seen from students' creativity, but also to the academic, social and behavior engagement.

\section{Conclusions}

Based on the result and discussion above can be concluded that there is positive effect toward students' learning outcome between students who taught with Think Pair Share and conventional teaching method where students in the think pair share class got the learning outcome is higher than conventional teaching class and based on students' higher creativity and lower creative showed that Think Pair Share method is better that conventional teaching method in students' achievement of social science, but there is no interaction between the think pair share method and creativity with the eighth grade students' learning outcomes of SMP Negeri 24 Padang.

\section{Acknowledgments}


This study was supported by State University of Padang. We thanks so much to our colleagues of Nora Afnita, M.Pdwho provided insight and expertise that greatly contribution to the research analysis. We also thanks a lot to Prof. Dr. Azwar Ananda, M.Pd and Dr. Buchari Nurdin M.Pd who help us in the particular technique, methodology and comments for greatly improvement of this paper.

\section{References}

Al-Dababneh, K. A., Al-Zboon, E. K., \& Ahmad, J. (2017). The creative environment: teachers' perceptions, self-efficacy, and teaching experience for fostering children's creativity. Early Child Development and Care, 0(0), 1-18. https://doi.org/10.1080/03004430.2017.1400969

Cooper, F. (2018). A Modification of Think Pair Share to Make it More Learner-Centered by Using Student-Generated Questions. College Teaching, 66(1), 34-34. https://doi.org/10.1080/87567555.2017.1390438

Creswell W John. (2014). Research Design, Qualitative, Quantitative and Mixed Methods Approaches (4th ed.). SAGE Publication, Inc.

Hwang, S. Y. (2017). Rethinking creativity: Present in expression in creative learning communities*. Educational Philosophy and Theory, 49(3), 220-230. https://doi.org/10.1080/00131857.2016.1225559

Kind, P. M., \& Kind, V. (2007). Creativity in science education: Perspectives and challenges for developing school science. Studies in Science Education, 43(1), 37. https://doi.org/10.1080/03057260708560225

Lawrence, C., Foster, V. A., \& Tieso, C. L. (2015). Creating Creative Clinicians: Incorporating Creativity Into Counselor Education. Journal of Creativity in Mental Health, 10(2), 166-180. https://doi.org/10.1080/15401383.2014.963188

Leyshon, C. (2014). Critical issues in social science climate change research. Contemporary Social Science, 9(4), 359-373. https://doi.org/10.1080/21582041.2014.974890

Ozkal, N. (2014). Relationships between teachers creativity fostering behaviors and their self-efficacy beliefs. Educational Research and Reviews, 9(18), 724-733. https://doi.org/10.5897/ERR2014.1816

Palmer, J. A. (1992). Connoisseurship and creativity: Monitoring creative thinking abilities in primary school children in england. Journal of Environmental Education, 23(3), 17-27. https://doi.org/10.1080/00958964.1992.9942798

Plucker, J., \& Beghetto, R. (2003). Why not be creative when we enhance creativity (In J. H. B). New York: Teachers College Press.

Rubenstein, L. D. V., McCoach, D. B., \& Siegle, D. (2013). Teaching for Creativity Scales: An Instrument to Examine Teachers' Perceptions of Factors That Allow for the Teaching of Creativity. Creativity Research Journal, 25(3), 324-334. https://doi.org/10.1080/10400419.2013.813807

Sulaiman Keshta, A., \& Seif, A. (2013). Evaluating the Higher Order Thinking Skills in Reading of English for Palestine Grade Eight. Asian Journal of Education and E-Learning, 1(1), 2321-2454.

Yang, K. K., Lee, L., Hong, Z. R., \& Lin, H. S. (2016). Investigation of effective strategies for developing creative science thinking. International Journal of Science Education, 38(13), 2133-2151. https://doi.org/10.1080/09500693.2016.1230685 